\title{
Ensuring staff training in integrated GUM services in transgender health issues is important: sexual health professionals (HCPs) want small group teaching
}

\author{
Bethan Machado ${ }^{1}$, Kate Nambiar ${ }^{1,2}$, Daniel Richardson ${ }^{1,2}$
}

1. Brighton and Sussex Medical School, Brighton, UK; 2. Brighton and Sussex University Hospital, Brighton, UK

\section{Background:}

- Estimated 1\% of the population in the UK is gender variant to some extent ${ }^{1}$.

- $1.2 \%(2,760)$ of the population of Brighton and Hove identify as transgender (trans) ${ }^{2}$.

- Large proportions of trans people engage in high risk behaviours, 2,3; trans women are one of the highest risk groups for HIV infection ${ }^{4}$; trans patients attend sexual health $(\mathrm{SH})$ clinics less frequently than non-trans patients ${ }^{5} \rightarrow$ providing good SH care to trans patients is vital.

- More specifically, trans people have previously reported that the information on SH available in Brighton and Hove was "not appropriate to their sexual practices"6.

Aim: To evaluate the current service relating to the care and management of trans patients within the Claude Nicol Centre, Brighton.

Methods: An electronic survey sent to all staff members working in integrated SH in Brighton.

\section{Results:}
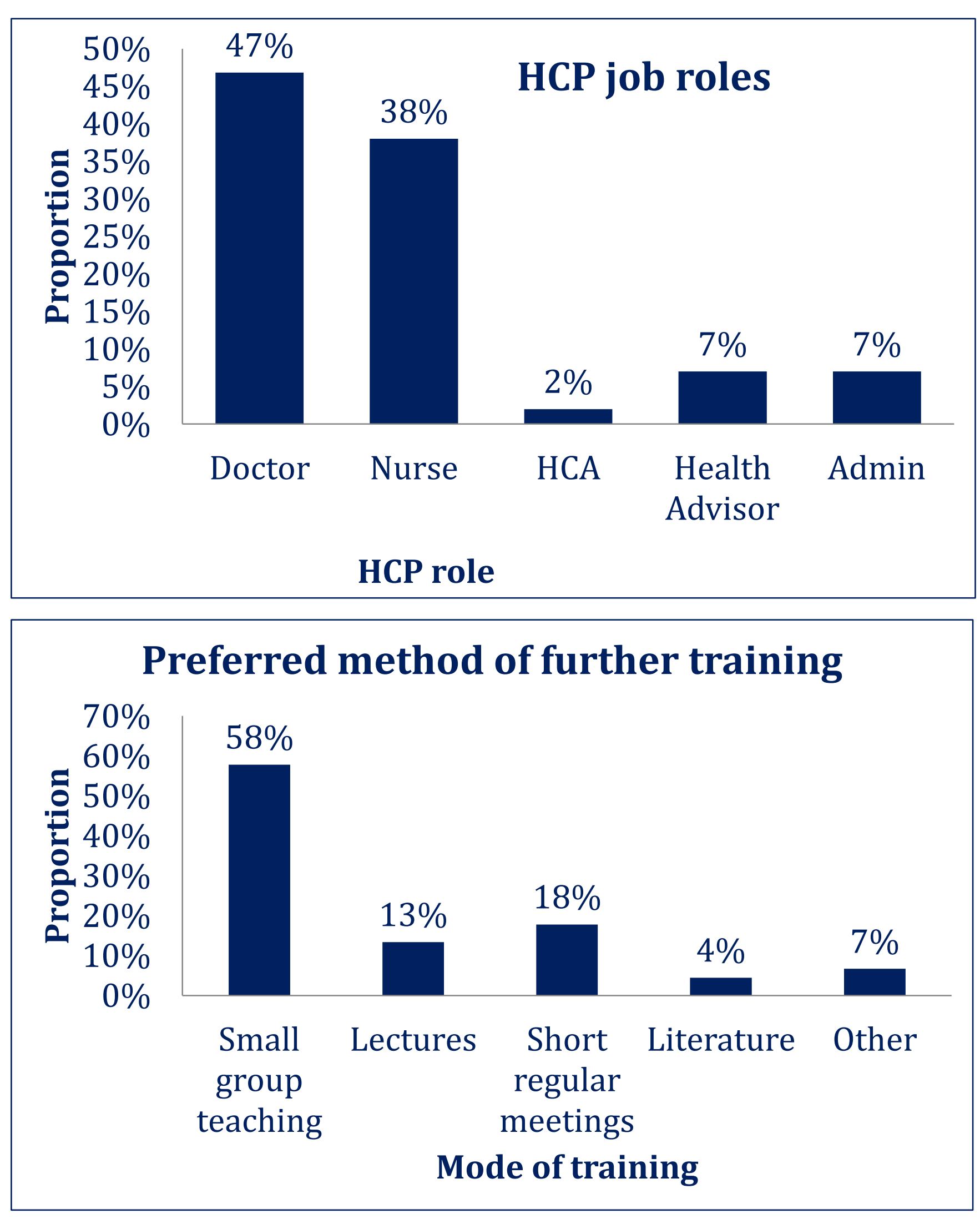

\begin{tabular}{|l|c|c|}
\hline $\begin{array}{l}\text { Confidence question } \\
\text { (Rated out of 5) }\end{array}$ & Mean & SD \\
\hline $\begin{array}{l}\text { Seeing trans patients in a clinical } \\
\text { setting }\end{array}$ & 3.00 & 1.00 \\
\hline Managing trans patients with SH needs & 3.33 & 1.30 \\
\hline $\begin{array}{l}\text { Managing trans patients with where to } \\
\text { seek further advice on gender } \\
\text { reassignment }\end{array}$ & 2.26 & 1.29 \\
\hline $\begin{array}{l}\text { Managing trans patients with where to } \\
\text { seek further advice on hormone } \\
\text { replacement }\end{array}$ & 1.93 & 1.18 \\
\hline $\begin{array}{l}\text { Managing trans patients with where to } \\
\text { seek further advice regarding } \\
\text { psychological issues }\end{array}$ & 2.72 & 1.20 \\
\hline $\begin{array}{l}\text { Managing trans patients with where to } \\
\text { seek additional support and advice in } \\
\text { the community }\end{array}$ & 2.47 & 1.37 \\
\hline
\end{tabular}

"31/45(69\%) of the respondents had been working in SH for at least 6 years.

"16/45(36\%) see trans patients at least three monthly in the Claude Nicol Centre and $29 / 45(64 \%)$ see trans patients less frequently than every 6 months.

\section{Recommendations:}

" Ensure that all staff working in sexual health are sufficiently trained in trans health care and feel confident in assessing and managing all aspects of care of trans patients.

" Introduce a trans-specific problem-based learning style of training to all HCPs working in sexual health.

" within the community are included in the training tool.

Sources

1. Royal College of Psychiatrists. Good practice guidelines for the assessment and treatment of adults with gender dysphoria. 2013.

2. Hill A, Condon R. Brighton and Hove Trans Needs Assessment 2015. Brighton and Hove: Brighton and Hove City Council.

3. Corliss HL et al. An evaluation of service utilization among male to female transgender youth: qualitative study of a clinic-based sample. J LGBT Health Res. 2007;3(2):49-61

4. Baral SD et al. Worldwide burden of HIV in transgender women: a systematic review and meta-analysis. Lancet Infect Dis. 2013;13(3):214-22

5. Bockting W et al. Patient satisfaction with transgender health services. J Sex Marital Ther. 2004;30(4):277-94. 